\title{
EFFECT OF POTASSIUM FERTILIZER, BIOSTIMULANTS AND EFFECTIVE MICROORGANISMS ON GROWTH, CARBOHYDRATES CONCENTRATION AND ION PERCENTAGE IN THE SHOOTS OF POTATO PLANTS
}

Arafa, A. A.; S. F. M. Hussin and Hager S. G. Mohamed

Agric. Bot. Dept., Fac. of Agric. Mansoura University

\begin{abstract}
Increasing potassium fertilizer rate up to $80 \mathrm{~kg} \mathrm{~K}$ O/fed significantly induced growth and carbohydrates concentration and ion percentage in potato shoots as compared to control in both seasons. The highest values was obtained due to application of $40 \mathrm{~kg} \mathrm{~K} \mathrm{~K}_{2} \mathrm{O} / \mathrm{fed}$ in the first and second seasons as compared with untreated plants. Addition of effective microorganisms and exogenous application of biostimulants, in particular, seaweed extract significantly increased shoot growth, carbohydrates concentration and ion percentage as compared to control in both seasons.

As for the interactions, application of biostimulants, in particular, seaweed extract, significantly increased shoot growth, carbohydrates concentration and ion percentage in potato shoots grown under all potassium fertilizer rates with or without an addition of effective microorganisms. The highest value was obtained under the treatment of $40 \mathrm{~kg} \mathrm{~K} \mathrm{~K}_{2} \mathrm{O} / \mathrm{fed}$ with addition of effective microorganisms and spraying plants with $500 \mathrm{mg} / \mathrm{l}$ seaweed extract as compared with control plant in the first and second growing seasons.
\end{abstract}

\section{INTRODUCTION}

Potato (Solanum tuberosum L.) is an important crop in terms of human food and starch industry. In Egypt the policy of the country aims to improve potato production so as to meet the increasing demand of the local consumption and to increase the amount of potato for exporting. Potato demands high level of soil nutrients due to relatively poorly developed and shallow root system in relation to yield (Perrenoud 1993). Compared with cereal crops, potato produces much more dry matter in a shorter cycle. This high rate of dry matter production results in large amounts of nutrients removed per unit time, which generally most of the soils are not able to supply. Hence, nutrient application from external sources as fertilizers becomes essential.

Potassium increases the photosynthetic rates of crop leaves and carbon dioxide $\left(\mathrm{CO}_{2}\right)$ assimilation, and facilitates carbon movement (Sangakkara et al. 2000). Elevated carbohydrate concentrations remaining in source tissue, such as leaves, appeared to be part of the overall effect of $K$ deficiency in reducing the amount of photosynthate available for reproductive sinks, thereby causing changes in lint yield and fiber quality in cotton (Pettigrew 1999). Although $\mathrm{K}^{+}$is not a constituent of any organic molecule or plant structure, it is involved in numerous biochemical and physiological processes vital to plant growth, yield, quality and stress (Cakmak 2005). In addition to stomatal regulation of transpiration and photosynthesis, $\mathrm{K}^{+}$is also involved in photophosphorylation, transportation of photoassimilates from 
Arafa, A. A. et al.

source tissues via the phloem to sink tissues, enzyme activation, turgor maintenance, and stress tolerance (Pettigrew 2008). Adequate $\mathrm{K}^{+}$nutrition has also been associated with increased yields, fruit size, increased soluble solids and ascorbic acid concentrations, improved fruit color, increased shelf life, and shipping quality of many horticultural crops (Kanai et al. 2007). Effective micro-organism (EM) as a biofertilizer was first used in Japan by Higa (1995). It promotes germination, flowering, fruiting and ripening, improves physical, chemical and biological environments of the soil and suppresses soil borne pathogens and pests. Furthermore, it enhances he photosynthetic capacity of crops.

Natural products, which contain phytohormones or exhibit hormonelike activity, have received increasing attention for use as nutrients supplements in agriculture and horticulture (Ezzat et al., 2011; Farouk et al., 2012). Seaweed extracts (Ascophyllum nodosum Jol.) and humic acid (HA) are in common use as major components of vegetable and crop biostimulant formulations. Auxin and cytokinin-like activities of humic acids and identified in SE have been reported (Piccolo et al. 1992). These natural products have been shown to enhance plant growth (Farouk et al., 2012). Exogenous applications of seaweed extracts have been observed to increase the yield and productivity of crop plants, but the mechanisms for such responses remain largely unknown (Featonby-Smith and van Staden 1987). Application of $\mathrm{HA}$ as foliar application with or without fertilizer increased significantly photosynthetic pigments content, yield and its components of tomato plants (Farouk et al., 2012). Application of seaweed extract or humic acid plus 50\% of recommended NPK significantly increased plant growth, yield and its components as well as tuber quality in potato plant (Ezzat et al. (2011). Therefore, the present investigation was planned to investigate the influence of various biostimulants (seaweed extract and humic acid) or effective microorganisms on certain growth characters, carbohydrate and ion percentage in the shoots of potato plant grown under potassium fertilization.

\section{MATERIALS AND METHODS}

Two field experiments were conducted during the two successive winter seasons of 2007/2008 and 2008/2009 at the EL-Maniel village, Dakahlia Governorate to study the effect of effective microorganisms, biostimulants, and potassium levels as well as their combinations on certain growth characters, carbohydrate and ion percentage in the shoots of potato plant.

Soil samples and analysis: Twenty surface samples $(0-20 \mathrm{~cm}$ depth) were taken at ten different locations. The experimental soil was air dried, grounded, mixed and kept in plastic bags for the analyses. The mechanical and chemical analyses of the soil used were carried out in the two growing seasons and presented in Table (I).

Plant Material, EM, Humic acid, and Seaweed Extract: Potatoes tubers; cv Spunta (imported from Holland) were used in the present investigation and obtained from Agric. Res. Center (ARC), Ministry of Agric., Egypt. Tubers 
were divided to pieces, averaging approximately $50 \mathrm{~g}$ weight. As recommended by the Pathology Dept. Ministry of Agric. Egypt, potato tubers pieces were sterilized with Vitavax Kapetan $1 \%$ at the rate of $1.25 \mathrm{~kg} / \mathrm{ton}$.

Table (1): Mechanical and chemical soil characteristics at the experimental sites during 2007/2008 and 2008/2009

\begin{tabular}{|c|c|c|c|c|c|c|c|c|}
\hline \multirow[b]{2}{*}{$\begin{array}{l}\text { Physical } \\
\text { properties }\end{array}$} & \multicolumn{2}{|c|}{ Value } & \multirow{2}{*}{$\begin{array}{l}\text { Chemical } \\
\text { properties }\end{array}$} & \multicolumn{2}{|c|}{ Value } & \multirow{2}{*}{$\begin{array}{l}\text { Available } \\
\text { nutrients } \\
\text { (mg Kg-1) }\end{array}$} & \multicolumn{2}{|c|}{ Value } \\
\hline & $\begin{array}{c}1^{\text {st }} \\
\text { season }\end{array}$ & $\begin{array}{c}2^{\text {nd }} \\
\text { season }\end{array}$ & & $1^{\text {st }}$ season & $\begin{array}{c}2^{\text {nd }} \\
\text { season }\end{array}$ & & $\begin{array}{c}1^{\text {st }} \\
\text { season }\end{array}$ & $\begin{array}{c}2^{\text {nd }} \\
\text { season }\end{array}$ \\
\hline Sand \% & 21.0 & 21.1 & $\begin{array}{c}\text { Field capacity } \\
\%\end{array}$ & 32 & rr & Nitrogen & 19 & 18 \\
\hline Silt\% & 32.3 & 33.0 & $\mathrm{EC}(\mathrm{dSm}-1)$ & 1.64 & 1.70 & phosphorous & 8 & 7 \\
\hline Clay \% & 46.0 & 45.8 & $\mathrm{pH}$ (Soil paste) & 7.82 & 7.75 & Potassium & 140 & 135 \\
\hline Soil texture & clay & & $\begin{array}{c}\text { Organic matter } \\
(\%)\end{array}$ & 2.69 & 2.80 & & & \\
\hline
\end{tabular}

Effective micro-organisms were used under the name of EM which consists of a mixed culture of beneficial micro-organisms primarily photosynthetic and lactic acid bacteria, yeast and streptomycetes. The number of each component was recorded in table (2)

Table (2): Components of EM used in the experiments

\begin{tabular}{|c|c|c|c|}
\hline Total bacterial & Lactic acid bacteria & Yeasts & Streptomycetes \\
\hline $2.5-9.6 \times 10^{4} \mathrm{cfu} / \mathrm{ml}$ & $6.6-9.9 \times 10^{6} \mathrm{cfu} / \mathrm{ml}$ & $10^{5}-10^{6} \mathrm{cfu} / \mathrm{ml}$ & $8.5 \times 10^{3} \mathrm{cfu} / \mathrm{ml}$ \\
\hline
\end{tabular}

An extract from brown seaweed (Acadian Seaplants, Dartmouth, Nova Scotia, Canada) prepared by a proprietary process. Seaweed extract is derived by an alkaline hydrolysis procedure from the fresh, intact Ascophyllum nodosum and $100 \%$ soluble in cold water. Seaweeds contained all the trace elements and plant growth hormones vitamins, amino acids, antibiotic and micronutrients (Crouch and Van Staden, 1993). Also seaweed extract contained protein/amino acids $3-5 \%$, lipid $1 \%$, alginic acid $12-18 \%$, fucose-containing polymers $12-15 \%$, mannitol $5-6 \%$, other carbohydrates 10-15\% (Acadian Seaplants Limited, Dartmoth, Nova Scotia, Canada), As described by Fike et al. (2001).

Experimental design: Farm yard manure has been added during soil preparation in organic fertilization at dose $\left(40 \mathrm{~m}^{3} / \mathrm{fed}\right.$.). The experiment comprised of 18 treatments including three different rates of potassium fertilizers used individually or in combinations with EM and biostimulants (Humic acid or seaweed extract). A randomized complete block design in factorial arrangement was used with three replicates. Each plot was $7.2 \mathrm{~m}^{2}$ $\left(2.25 \times 3.20 \mathrm{~m}^{2}\right)$ included three ridges, each three meters long and $70 \mathrm{~cm}$ apart; the distance between hills was $30 \mathrm{~cm}$ apart.

Planting procedure: Potato tuber cv. Spunta was planted in the ridges at 12 $15 \mathrm{~cm}$ in depth $\left(30-40 \mathrm{~cm}\right.$ apart) on October $27^{\text {th }}$ in the first season $2007 / 2008$ and on November $9^{\text {th }}$ in the second season 2008/2009 respectively. Potassium (K) levels occupied the main plots, while the effective microorganisms (EM) were assigned to the sub-plots, in each EM sub-plot the plants were divided into three groups which sprayed with either water (W), seaweed extract (SW) or humic acid (HA). The plot area was $7.2 \mathrm{~m}^{2}$ 
Arafa, A. A. et al.

ridged $70 \mathrm{~cm}$ apart. As recommended by the Agric. Res. Center, Egypt, Nitrogen fertilizer was added at three equal portions, the $1^{\text {st }}$ was applied after emergence (18-21 days from planting), in the form of ammonium sulphate $(20.5 \%)$, then two and four weeks later in the form of ammonium nitrate (33.5 $\%)$ at the rate of $180 \mathrm{Kg} \mathrm{N} /$ fed. Phosphorous and potassium were applied during the soil preparation in the form of calcium superphosphate $(15.5 \%$ $\left.\mathrm{P}_{2} \mathrm{O}_{5}\right)$ and potassium sulphate $\left(48 \% \mathrm{~K}_{2} \mathrm{O}\right)$ at rate of $75 \mathrm{~kg} \mathrm{P}_{2} \mathrm{O}_{5} / \mathrm{fed}$ and 20 $\mathrm{kg} \mathrm{K}_{2} \mathrm{O}$ fed $^{-1}$ respectively. The respective EM treated plots received dilute EM solution 2 liter $/ \mathrm{m}^{2}$ before the first irrigation. Potassium fertilizers applied at three levels 0,40 and $80 \mathrm{~kg} \mathrm{~K}_{2} \mathrm{O}$ fed $^{-1}$ using potassium sulphate $\left(48 \% \mathrm{~K}_{2} \mathrm{O}\right)$. The quantity was divided into two equal doses to be added before the first irrigation and before the second irrigation. Plants were sprayed with an aqueous solution of SW or HA two times at 60 and 75 days from planting. Irrigation was done immediately. All usual cultural practices of potatoes cultivation were carried out according to the procedures that recommended by the Ministry of Agric. Egypt.

Sampling dates and data recorded: One plant sample was taken throughout the experimental period during the two growing seasons, for the growth characters and estimation of both carbohydrate and ion concentrations as well as leaflet anatomy coincide as best as possible at the physiological stage of 22 foliage leaves; dated at the active growth period (after 90 days from planting). Three plants were chosen randomly and carefully taken out of the soil with the aid of a water stream to insure minimal losses of the root system and the tubers if present. Shoots were divided into stems and leaves. Shoot length $(\mathrm{cm})$ of the aerial main stem, started from the soil surface to plant apex. Numbers of branches and leaves per plant leaf area per plant $\left(\mathrm{cm}^{2}\right)$, calculated as presented below were recorded. Leaf area per plant calculated based on area unit using disk method according to (Koller, 1972). Briefly, samples of ten disks were taken from the 3rd fresh leaf from plant tip and estimated their area. Leaf area per plant was calculated in square centimeters $\left(\mathrm{cm}^{2}\right)$ using the following equation:

Leaf area $(\mathrm{cm})^{2}$ per plant $=$ Disk area of 10 disks $\left(\mathrm{cm}^{2}\right) \times$ fresh weight of the leaves Fresh weight of 10 disks

Total carbohydrates concentration: The dried leaves were extracted by adding sulphoric acid $(1 \mathrm{~N})$ in boiling water bath for $5 \mathrm{~h}$. then filtration through whatman number 42 filter papers. The total carbohydrates were determined by phenol-sulphoric acid methods as described by Sadasivam and Manickam (1996). For ion percentage, ground dried stem, leaf and tuber samples were wet digested with $\mathrm{HClO}_{3} / \mathrm{H}_{2} \mathrm{SO}_{4}$ until the solution was clear, cooled, and brought to volume at $100 \mathrm{ml}$ using deionized water and kept for determinations. Nitrogen was determined calorimetrically by Nessler's methods as described by Gedroits (1963), phosphorous was determined spectrophotometrically (Spekol 11, Uk) by the methods described by Cooper (1977) using ammonium molybdate and ascorbic acid. Potassium was determined flame photometrically using Jenway Flamephotometer model CORNING 400 (UK). 


\section{Statistical analysis:}

Data were subjected to statistical analysis of variance according to Norman and Streiner, 2003. LSD value was used to test the difference between treatment means at $5 \%$.

\section{RESULTS}

Shoot Length: Data illustrated in figure (3) show that increasing potassium fertilizer rate significantly increased potato shoot length in both seasons. Potassium fertilizer at $40 \mathrm{~kg} \mathrm{~K} 2 \mathrm{O} / \mathrm{fed}$ gave the highest values since increased shoot length from $56.60 \mathrm{~cm}$ and $57.55 \mathrm{~cm}$ to $63.05 \mathrm{~cm}$ and $64.11 \mathrm{~cm}$ in both growing seasons respectively. The same trend was apparent due to addition of effective microorganisms to potato shoot in both seasons, where shoot length increased from $58.59 \mathrm{~cm}$ and $59.18 \mathrm{~cm}$ to $60.77 \mathrm{~cm}$ and $61.59 \mathrm{~cm}$ in both growing seasons respectively. Regarding the effect of biostimulants, the data illustrated in figure (1) reveal that potato shoot length was significantly increased by spraying both biostimulants, in particular, seaweed extract which gave the highest value in this respect in both seasons.

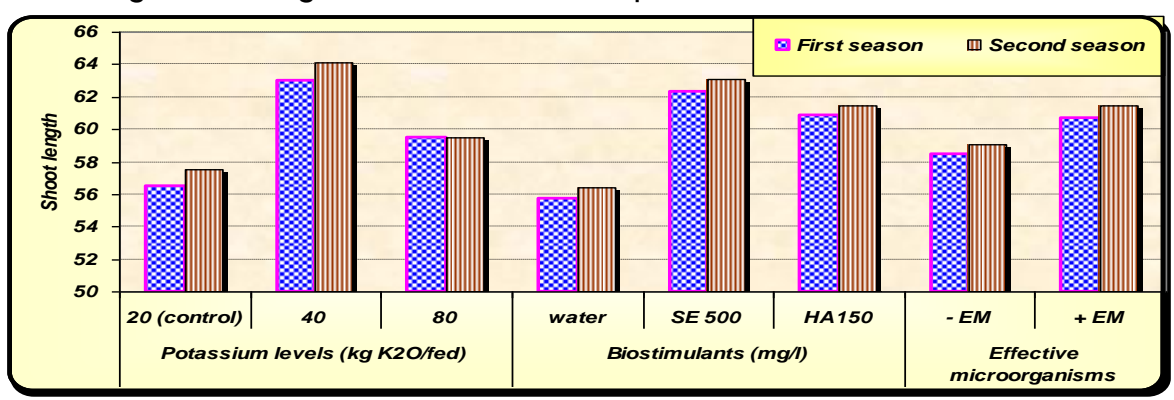

Figure (1): Shoot length (cm) of potato plant as affected by potassium fertilizer, biostimulants or effective microorganisms at 90 days from planting in both season (SE, Seaweed extract; HA, Humic acid)

Table (3): Shoot length $(\mathrm{cm})$ of potato plant as affected by the interactions between potassium fertilizer (A), effective microorganisms (B) and biostimulants (C) at 90 days from planting during the first and second season

\begin{tabular}{|c|c|c|c|c|c|c|}
\hline \multirow{2}{*}{ Treatment } & \multicolumn{7}{|c|}{ First season } \\
\cline { 2 - 7 } & \multicolumn{7}{|c|}{ KM } & \multicolumn{4}{c|}{ + EM } \\
\cline { 2 - 7 } & K20 & K40 & K80 & K20 & K40 & K80 \\
\hline Water & 49.66 & 59.33 & 55.33 & 52.00 & 61.00 & 57.00 \\
\hline SE & 59.66 & 64.66 & 60.33 & 60.33 & 65.66 & 63.66 \\
\hline HA & 57.00 & 63.66 & 57.66 & 60.33 & 64.00 & 63.00 \\
\hline LSD 5\% & A 3.067 & \multicolumn{7}{|c|}{ B 2.056 } & C 3.179 & ABC NS \\
\hline Water & 52.33 & 59.00 & 54.00 & 53.66 & 62.33 & 57.33 \\
\hline SE & 60.00 & 66.33 & 60.66 & 61.00 & 67.66 & 63.33 \\
\hline HA & 57.66 & 64.33 & 58.33 & 60.66 & 65.00 & 63.33 \\
\hline LSD 5\% & A 2.640 & \multicolumn{7}{|c|}{ B 1.106 } & C 1.937 & ABC NS \\
\hline
\end{tabular}

(K20, 20 kg K2O/ fed; K40, 40 kg K2O/ fed; K80, 80 kg K2O/ fed; SE, seaweed extract; HA, humic acid) 
Arafa, A. A. et al.

Concerning the interactions effects, the data presented in table (3) indicate that application of either seaweed extract or humic acid with or without an addition of effective microorganisms under all potassium levels did not-significantly increased shoot length in both seasons compared with untreated one. It is clear also from the same table that seaweed extract caused a significant increase in potato shoot length grown under moderate potassium level and inoculation with effective microorganisms which gave the best results in this respect.

Branches number per plant: Data illustrated in figure (2) indicate that addition of potassium fertilizer rate from $20 \mathrm{~kg} \mathrm{~K} 2 \mathrm{O} / \mathrm{fed}$ (control) to $80 \mathrm{~kg}$ $\mathrm{K}_{2} \mathrm{O} / \mathrm{fed}$ significantly increased branches number per plant. The highest number was obtained due to $40 \mathrm{~kg} \mathrm{~K} 2 \mathrm{O} / \mathrm{fed}$. The same trend was obtained due to addition of effective microorganisms to potato plants. The same figure also reveals that application of biostimulants, in particular, seaweed extract at $500 \mathrm{mg} / \mathrm{l}$ significantly increased branches number per plants. Spraying potato plants with seaweed extract gave the highest number of branches per plant (8.16 and 8.50 branches/plant) as compared with humic acid (7.72 and 7.88 branches/plant) as well as control (6.44 and 6.38 branches/plant) during the two growing seasons.

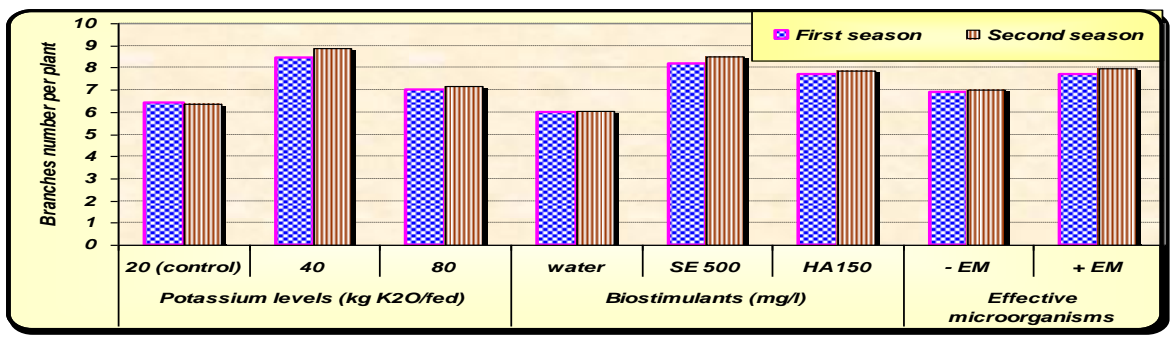

Figure (2): Branches number per potato plant as affected by potassium fertilizer, biostimulants or effective microorganisms at 90 days from planting in both season (SE, Seaweed extract; HA, Humic acid)

Table (4):Branches number per of potato plant as affected by the interactions between potassium fertilizer (A), effective microorganisms (B) and biostimulants (C) at 90 days from planting during the first and second season

\begin{tabular}{|c|c|c|c|c|c|c|}
\hline \multirow{3}{*}{ Treatment } & \multicolumn{6}{|c|}{ First season } \\
\hline & \multicolumn{3}{|c|}{ - EM } & \multicolumn{3}{|c|}{$+E M$} \\
\hline & K20 & K40 & K80 & K20 & K40 & K80 \\
\hline Water & 4.66 & 7.00 & 5.33 & 5.00 & 8.00 & 6.00 \\
\hline SE & 7.00 & 9.00 & 7.33 & 8.00 & 9.33 & 8.33 \\
\hline $\mathrm{HA}$ & 6.33 & 8.66 & 6.66 & 7.66 & 8.66 & 8.33 \\
\hline LSD 5\% & \multicolumn{2}{|l|}{ A 1.486} & $\begin{array}{c}1 \\
\text { B } 0.684\end{array}$ & \multicolumn{2}{|c|}{ C 0.592} & ABC NS \\
\hline \multicolumn{7}{|c|}{ Second season } \\
\hline Water & 4.33 & 7.00 & 5.66 & 5.00 & 8.66 & 5.66 \\
\hline $\mathrm{SE}$ & 7.33 & 9.66 & 7.33 & 8.00 & 9.66 & 9.00 \\
\hline $\mathrm{HA}$ & \begin{tabular}{l|l}
6.00 \\
\end{tabular} & 9.00 & 6.66 & 7.66 & 9.33 & 8.66 \\
\hline LSD 5\% & \multicolumn{2}{|l|}{ A 1.302} & & \multicolumn{2}{|c|}{ C 0.668} & $\frac{1}{A B C N S}$ \\
\hline
\end{tabular}

(K20, 20 kg K2O/ fed; K40, 40 kg K2O/ fed; K80, 80 kg K2O/ fed; SE, seaweed extract; HA humic acid) 
Data presented in Table (4) show that spraying potato plants with biostimulants under addition of effective microorganisms with or without potassium fertilizers rate significantly increased the number of branches per plant. The highest number of branche per potato plant in both season was obtained under the treatment of foliar application of $500 \mathrm{mg} / \mathrm{l}$ seaweed extract under addition of effective microorganisms with addition of $40 \mathrm{~kg} \mathrm{~K}_{2} \mathrm{O} / \mathrm{fed}$ (9.33 and 9.66 branches per plant) as compared with control plants which gave the lowest branches number per plant in both growing season (4.66 and 4.33 branches/plant) respectively.

Leaf number per plant: The data presented in Table (5) and illustrated in Figure (3) show that the number of leaves per plant was significantly increased due to application of potassium fertilizer, effective microorganisms and biostimulants application as compared with untreated plants in such case. The highest values of leaf number in both seasons were obtained due to application of $40 \mathrm{~kg} / \mathrm{fed} \mathrm{K}_{2} \mathrm{O}$, and addition of effective microorganisms as well as $500 \mathrm{mg} / \mathrm{l}$ seaweed extract. As regard to the interaction effect of potassium fertilizer rate, effective microorganisms and biostimulants application, the data presented in Table (7) cleary indicate that all interactions in both growing season non-significantly increased leaf number per plant. The highest values in both seasons were obtained due to addition $40 \mathrm{~K}_{2} \mathrm{O} \mathrm{kg} / \mathrm{fed}$ with addition of biostimulants and foliar spraying with seaweed extract.

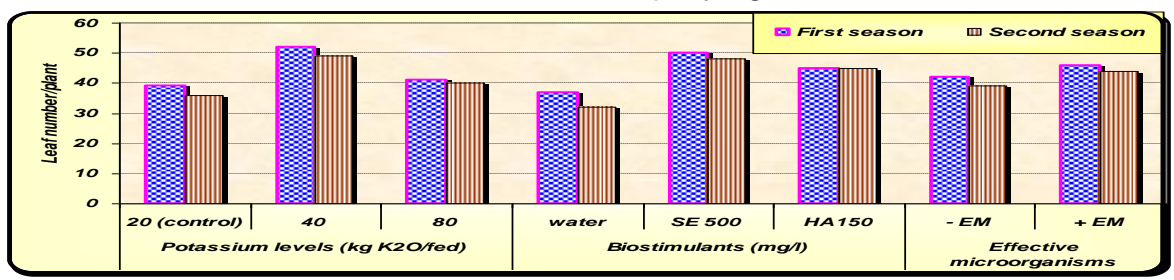

Figure (3): Leaf number per potato plant as affected by potassium fertilizer, biostimulants or effective microorganisms at 90 days from planting in both season (SE, Seaweed extract; HA, Humic acid)

Table (5): Leaf number per potato plant as affected by the interactions between potassium fertilizer (A), effective microorganisms (B) and biostimulants (C) at 90 days from planting during the first and second season

\begin{tabular}{|c|c|c|c|c|c|c|}
\hline \multirow{3}{*}{ Treatment } & \multicolumn{6}{|c|}{ First season } \\
\hline & \multicolumn{3}{|c|}{ - EM } & \multicolumn{3}{|c|}{$+E M$} \\
\hline & K20 & K40 & K80 & K20 & K40 & K80 \\
\hline Water & 31.6 & 39.3 & 36.6 & 36.0 & 44.6 & 37.3 \\
\hline SE & 41.0 & 60.0 & 42.6 & 44.0 & 65.0 & 47.3 \\
\hline $\mathrm{HA}$ & 37.6 & 51.3 & 37.6 & 45.0 & 54.3 & 46.6 \\
\hline LSD 5\% & A 6.678 & & & C 3.8 & & \\
\hline \multicolumn{7}{|c|}{ Second season } \\
\hline Water & 22.6 & 43.0 & 25.6 & 24.3 & 45.6 & 33.6 \\
\hline SE & 43.3 & 51.3 & 44.3 & 45.6 & 56.0 & 49.0 \\
\hline $\mathrm{HA}$ & 37.0 & 49.0 & 41.3 & 45.3 & 51.0 & 49.0 \\
\hline LSD 5\% & A 8.111 & \multicolumn{2}{|c|}{ B 2.834} & C 2.2 & \multicolumn{2}{|c|}{$A B C N S$} \\
\hline
\end{tabular}

$\left(\mathrm{K}_{20}, 20 \mathrm{~kg} \mathrm{~K} \mathrm{~K}_{2} \mathrm{O} / \mathrm{fed} ; \mathrm{K}_{40}, 40 \mathrm{~kg} \mathrm{~K} \mathrm{~K}_{2} \mathrm{O} / \mathrm{fed} ; \mathrm{K}_{80}, 80 \mathrm{~kg} \mathrm{~K} \mathrm{~K}_{2} \mathrm{O}\right.$ fed; SE, seaweed extract; HA humic acid) 
Arafa, A. A. et al.

Leaf area per plant: Data illustrated in figure (4) and presented in table (6) show that leaf area per plant at 90 days from planting significantly increased with increasing potassium levels up to $80 \mathrm{~kg} \mathrm{~K} \mathrm{~K}_{2} \mathrm{O} / \mathrm{fed}$. The highest leaf area (890 and $1050 \mathrm{~cm}^{2} /$ plant) was obtained due to addition of $40 \mathrm{~kg} \mathrm{~K} \mathrm{~K}_{2} \mathrm{O} / \mathrm{fed}$ thereafter tended to decrease but still more than control (484- $546 \mathrm{~cm}^{2} /$ plant). Regarding the effect of biostimulants on leaf area per plant, the data illustrated in the same figure clearly show that either SE or HA application significantly increased leaf area per plant in both seasons. SE proved to be more effective than HA in this respect, where foliar application of $500 \mathrm{mg} / \mathrm{SE}$ increased leaf area per plants from $454-559 \mathrm{~cm}^{2}$ to $806-944 \mathrm{~cm}^{2}$ in the first and second season. As regard, to the effect of addition of EM to potato plants the same figure indicates that addition of EM increased leaf area per plant in both season.

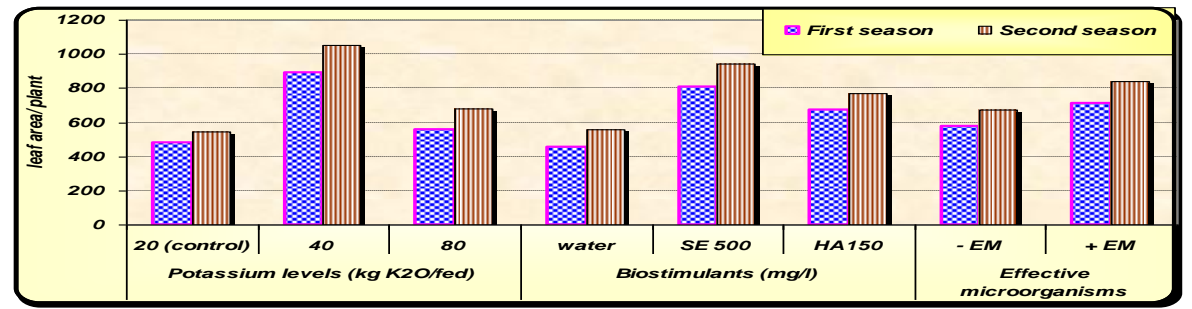

Figure (4): leaf area per potato plant (cm2) as affected by potassium fertilizer, biostimulants or effective microorganisms at 90 days from planting in both season (SE, Seaweed extract; HA, Humic acid)

Table (6): leaf area per potato plant $\left(\mathrm{cm}^{2}\right)$ as affected by the interactions between potassium fertilizer (A), effective microorganisms (B) and biostimulants (C) at 90 days from planting during the first and second seasons

\begin{tabular}{|c|c|c|c|c|c|c|}
\hline \multirow{3}{*}{ Treatment } & \multicolumn{6}{|c|}{ First season } \\
\hline & \multicolumn{3}{|c|}{ - EM } & \multicolumn{3}{|c|}{$+E M$} \\
\hline & K20 & K40 & K80 & K20 & K40 & K80 \\
\hline Water & 389 & 498 & 407 & 399 & 580 & 453 \\
\hline SE & 514 & 1119 & 522 & 573 & 1356 & 753 \\
\hline $\mathrm{HA}$ & 464 & 796 & 491 & 565 & 990 & 737 \\
\hline LSD 5\% & \multicolumn{2}{|c|}{ A 39.97} & 36.18 & \multicolumn{2}{|l|}{ C 24.44} & $\begin{array}{c}1 \\
\mathrm{ABC}\end{array}$ \\
\hline \multicolumn{7}{|c|}{ Second season } \\
\hline Water & 399 & 563 & 511 & 443 & 892 & 545 \\
\hline SE & 594 & 1352 & 608 & 674 & 1505 & 935 \\
\hline $\mathrm{HA}$ & 556 & 950 & 557 & 609 & 1040 & 910 \\
\hline LSD 5\% & A 1 & & 26.92 & C 44.6 & $\mathrm{Al}$ & 09.45 \\
\hline
\end{tabular}

( $\mathrm{K}_{20}, 20 \mathrm{~kg} \mathrm{~K} \mathrm{~K}_{2} \mathrm{O}$ fed; $\mathrm{K}_{40}, 40 \mathrm{~kg} \mathrm{~K} \mathrm{~K}_{2} \mathrm{O}$ fed; $\mathrm{K}_{80}, 80 \mathrm{~kg} \mathrm{~K} \mathrm{~K}_{2} \mathrm{O}$ fed; SE, seaweed extract; $\mathrm{HA}$, humic acid)

As regard to the interactions between potassium levels, occurrence of EM and spraying plants with biostimulants, the data in Table (9) show that foliar application of biostimulants, in particular, $500 \mathrm{mg} / \mathrm{SE}$, to the plants grown under potassium levels and occurrence of EM significantly increased leaf area per plant. The best results were obtained due to spraying plants 
with SE under an addition of EM to the soil containing moderate potassium levels $\left(40 \mathrm{~kg} \mathrm{~K} 2 \mathrm{O} / \mathrm{fed}\right.$ ) which increased leaf area per plant from $389-399 \mathrm{~cm}^{2}$ to $1356-1505 \mathrm{~cm}^{2}$ in both seasons respectively.

Carbohydrate concentration: Data illustrated in figure (5) clearly indicated that all applied treatments significantly increased carbohydrates concentration in both leaves and stems during the second season as compared with untreated plants. The same figure cleary showed that an addition of potassium fertilizer, in particular, $40 \mathrm{~kg} \mathrm{~K} 2 \mathrm{O} / \mathrm{fed}$ significantly increased total carbohydrates in both leaves and stems (96.22 and 83.61 $\mathrm{mg} / \mathrm{g}$ DW respectively) as compared with control plants which gave $20 \mathrm{~kg}$ $\mathrm{K}_{2} \mathrm{O} / \mathrm{fed}$. (71.87 and $57.95 \mathrm{mg} / \mathrm{kg} \mathrm{DW}$ ). Foliar application with either SE or HA significantly increased total carbohydrate concentration in both leaves and stems as compared with control. SE proved to be more effective than HA in increasing the concentration of total carbohydrates in leaves and stems. Concerning the effective microorganisms, the data illustrated in the same figure indicated that an addition of EM to the plants increased total carbohydrates concentration from 76.99 and $63.39 \mathrm{mg} / \mathrm{g}$ DW to 87.54 and $74.80 \mathrm{mg} / \mathrm{g} \mathrm{DW}$ for leaf and stem respectively in the second season.

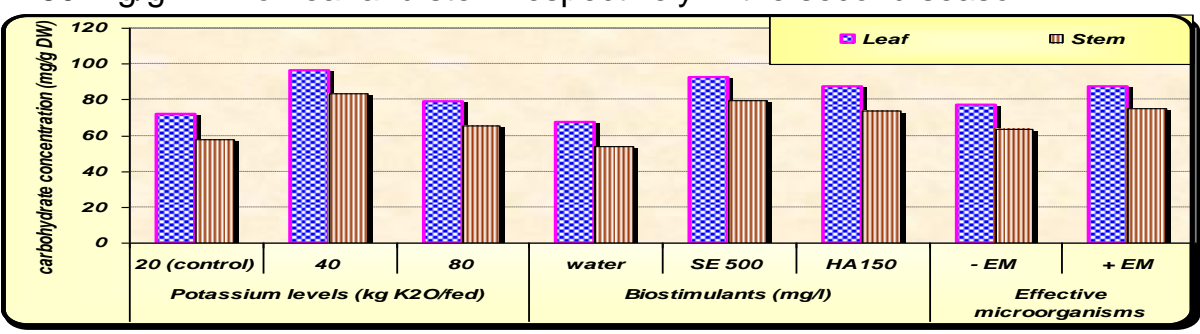

Figure (5):Total carbohydrate concentration ( $\mathrm{mg} / \mathrm{g} \mathrm{DW}$ ) in both leaves and stems of potato plant as affected by potassium fertilizer, biostimulants or effective microorganisms at 90 days from planting during the second growing season (SE, Seaweed extract; HA, Humic acid)

Table (7): Total carbohydrates concentration ( $\mathrm{mg} / \mathrm{g} \mathrm{DW}$ ) in both leaves and stems of potato plant as affected by the interactions between potassium fertilizer (A), effective microorganisms (B) and biostimulants (C) at 90 days from planting during the second growing season

\begin{tabular}{|c|c|c|c|c|c|c|}
\hline \multirow{3}{*}{ Treatment } & \multicolumn{6}{|c|}{ Leaves } \\
\hline & \multicolumn{3}{|c|}{ - EM } & \multicolumn{3}{|c|}{$+\mathrm{EM}$} \\
\hline & K20 & K40 & K80 & K20 & K40 & K80 \\
\hline Water & 53.27 & 74.79 & 62.78 & 58.66 & 90.24 & 65.28 \\
\hline SE & 77.37 & 103.60 & 80.57 & 88.08 & 107.56 & 96.75 \\
\hline $\mathrm{HA}$ & \begin{tabular}{l|l}
68.71 \\
\end{tabular} & 99.29 & \begin{tabular}{l|l} 
& 72.52 \\
\end{tabular} & 85.11 & 101.86 & 94.29 \\
\hline LSD 5\% & \multicolumn{2}{|l|}{ A 0.4216} & B 0.2682 & \multicolumn{2}{|c|}{ C 0.5359} & ABC 1.3126 \\
\hline \multicolumn{7}{|c|}{ Stem } \\
\hline Water & 34.56 & 62.32 & 50.23 & 46.10 & 77.53 & 52.35 \\
\hline SE & 64.09 & 91.47 & 66.86 & 75.22 & 94.55 & 84.96 \\
\hline $\mathrm{HA}$ & 55.73 & 86.62 & \begin{tabular}{l|l} 
& 58.62
\end{tabular} & 71.98 & 89.16 & 81.38 \\
\hline LSD 5\% & A 1.9205 & \multicolumn{2}{|r|}{ B 1.3484} & C 1.03 & \multicolumn{2}{|c|}{ ABC 2.5450} \\
\hline
\end{tabular}

$\left(\mathrm{K}_{20}, 20 \mathrm{~kg} \mathrm{~K} \mathrm{O} / \mathrm{fed} ; \mathrm{K}_{40}, 40 \mathrm{~kg} \mathrm{~K} \mathrm{~K}_{2} \mathrm{O}\right.$ fed; $\mathrm{K}_{80}, 80 \mathrm{~kg} \mathrm{~K} \mathrm{O} / \mathrm{fed}$; SE, seaweed extract; HA humic acid) 
Arafa, A. A. et al.

Regarding the interactions, the data presented in Table (7) showed that there is a significant increase in total carbohydrates concentration in both leaves and stems due to the interactions between the studied factors. The highest value was obtained due to inoculated potato plants with EM supplemented with $40 \mathrm{Kg} \mathrm{K}$ O/fed and spraying the plant shoots with seaweed extract. This treatment gave 107.56 and $94.55 \mathrm{mg} / \mathrm{g}$ DW for leaf and stem as compared with control plant (53.27 and $34.56 \mathrm{mg} . \mathrm{g}$ DW for leaf and stem) respectively.

Ion percentage: It is clear from the results presented in Tables (8-10) and illustrated in Figures (6-8) that nitrogen, phosphorous and potassium percentage in leaf and stem were significantly increased due to an addition of potassium fertilizer levels. The highest values of nitrogen and phosphorous were recorded due to $40 \mathrm{~kg} \mathrm{~K} 2 \mathrm{O} / \mathrm{fed}$ in either leaf or stem of potato plants. Meanwhile, potassium percentage in leaf and stem significantly increased with increasing potassium doses and the highest value was obtained due to $80 \mathrm{Kg} \mathrm{K} 2 \mathrm{O} / \mathrm{fed}$.

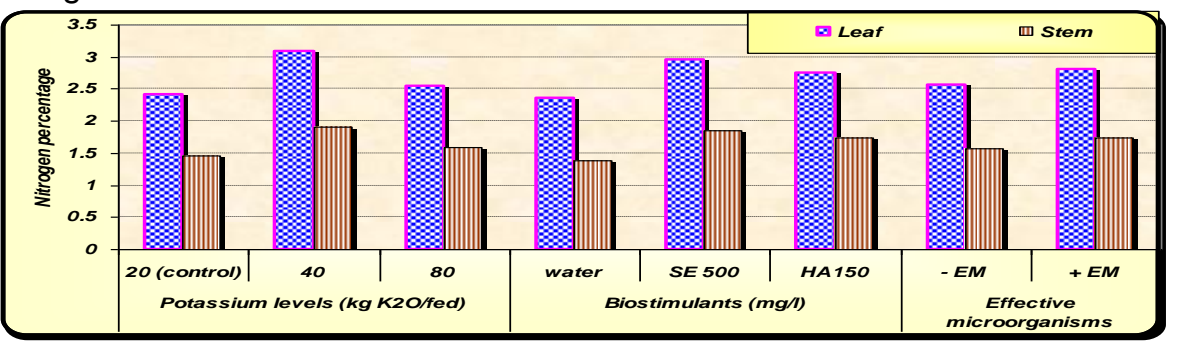

Figure (6): Nitrogen percentage in both leaf and stem of potato plant as affected by potassium fertilizer, biostimulants or effective microorganisms at 90 days from planting in the second growing season (SE, Seaweed extract; HA, Humic acid)

Table (8): Nitrogen percentage in both leaf and stem of potato plant as affected by the interactions between potassium fertilizer (A), effective microorganisms (B) and biostimulants (C) at 90 days from planting during the second growing season

\begin{tabular}{|c|c|c|c|c|c|c|}
\hline \multirow{3}{*}{ Treatment } & \multicolumn{6}{|c|}{ Leaves } \\
\hline & \multicolumn{3}{|c|}{ - EM } & \multicolumn{3}{|c|}{$+\mathrm{EM}$} \\
\hline & K20 & K40 & K80 & K20 & K40 & K80 \\
\hline Water & 2.155 & 2.43 & 2.231 & 2.193 & 2.805 & 2.303 \\
\hline SE & 2.523 & 3.404 & 2.569 & 2.694 & 3.607 & 2.949 \\
\hline $\mathrm{HA}$ & 2.317 & 3.063 & 2.375 & 2.607 & 3.232 & 2.867 \\
\hline LSD 5\% & \multicolumn{2}{|c|}{ A 0.0463} & 200 & \multicolumn{2}{|c|}{ C 0.0154} & $\mathrm{ABC} 0.0376$ \\
\hline \multicolumn{7}{|c|}{ Stem } \\
\hline Water & 1.135 & 1.531 & 1.274 & 1.198 & 1.790 & 1.374 \\
\hline SE & 1.596 & 2.061 & 1.645 & 1.733 & 2.131 & 1.898 \\
\hline $\mathrm{HA}$ & 1.452 & 1.981 & 1.501 & 1.677 & 1.998 & 1.842 \\
\hline LSD 5\% & \multicolumn{2}{|c|}{ A 0.0098} & 058 & \multicolumn{2}{|c|}{ C 0.0175} & ABC 0.0432 \\
\hline
\end{tabular}

$\left(\mathrm{K}_{20}, 20 \mathrm{~kg} \mathrm{~K}\right.$ O/ fed; $\mathrm{K}_{40}, 40$ kg K $\mathrm{K}_{2} \mathrm{O}$ / fed; $\mathrm{K}_{80}, 80 \mathrm{~kg} \mathrm{~K}$ O/ fed; SE, seaweed extract; HA humic acid)

As regard to the effect of biostimulants on ion percentage in potato leaf and stem, the data illustrated in Figures (6-8) indicated that exogenous 
application of both biostimulants, in particular, seaweed extract significantly increased ion percentage. The highest values of nitrogen, phosphorous and potassium in both leaf and stem (2.958 and 1.844; 1.067 and 0.736; 2.595 and $2.156 \%$ ) were obtained due to seaweed foliar application, comparing with untreated control plant (2.353 and 1.384; 0.647 and $0.533 ; 2.338$ and $1.875 \%$ respectively). Concerning the role of effective microorganisms on ion content, the same figure clearly proved that an addition of EM to potato plants significantly increased ion percentage in both leaf and stem during the second season.

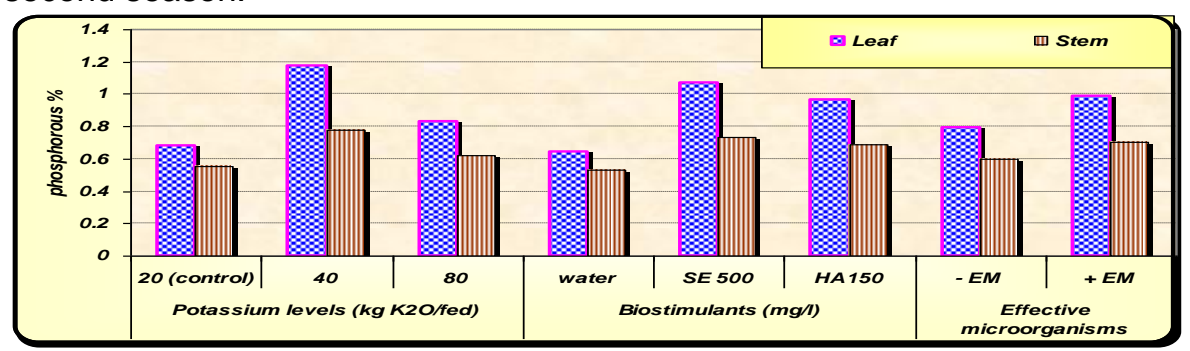

Figure (7): Phosphorous percentage in both leaves and stem of potato plant as affected by potassium fertilizer, biostimulants or effective microorganisms at $\mathbf{9 0}$ days from planting in the second growing season (SE, Seaweed extract; HA, Humic acid)

Table (9): Phosphorous percentage in both leaves and stem of potato plant as affected by the interactions between potassium fertilizer (A), effective microorganisms (B) and biostimulants (C) at 90 days from planting during the second growing season

\begin{tabular}{|c|c|c|c|c|c|c|}
\hline \multirow{3}{*}{ Treatment } & \multicolumn{6}{|c|}{ Leaves } \\
\hline & \multicolumn{3}{|c|}{ - EM } & \multicolumn{3}{|c|}{$+\mathrm{EM}$} \\
\hline & K20 & K40 & K80 & K20 & K40 & K80 \\
\hline Water & 0.461 & 0.738 & 0.564 & 0.464 & 1.082 & 0.572 \\
\hline SE & 0.755 & 1.333 & 0.803 & 0.968 & 1.370 & 1.174 \\
\hline $\mathrm{HA}$ & 0.577 & 1.233 & \begin{tabular}{l|l} 
& 0.698 \\
\end{tabular} & 0.847 & 1.275 & 1.157 \\
\hline LSD 5\% & \multicolumn{2}{|c|}{\begin{tabular}{l|l} 
A 0.7852 & \\
\end{tabular}} & 0.0398 & C 0.061 & \multicolumn{2}{|c|}{ ABC 0.1503} \\
\hline \multicolumn{7}{|l|}{ Stem } \\
\hline Water & 0.392 & 0.570 & 0.520 & 0.476 & 0.717 & 0.525 \\
\hline SE & 0.575 & 0.836 & 0.600 & 0.676 & 0.913 & 0.815 \\
\hline $\mathrm{HA}$ & 0.553 & 0.816 & 0.558 & \multirow{2}{*}{\multicolumn{2}{|c|}{$\frac{0.654}{C 0.0429}$}} & 0.731 \\
\hline LSD 5\% & \multicolumn{2}{|c|}{ A 0.0588} & 0.0339 & & & .1068 \\
\hline
\end{tabular}

$\left(\mathrm{K}_{20}, 20 \mathrm{~kg} \mathrm{~K} \mathrm{~K}_{2} \mathrm{O}\right.$ fed; $\mathrm{K}_{40}, 40 \mathrm{~kg} \mathrm{~K} \mathrm{~K}_{2} \mathrm{O} / \mathrm{fed} ; \mathrm{K}_{80}, 80 \mathrm{~kg} \mathrm{~K} \mathrm{~K}_{2} \mathrm{O}$ / fed; SE, seaweed extract; $\mathrm{HA}$, humic acid) 
Arafa, A. A. et al.

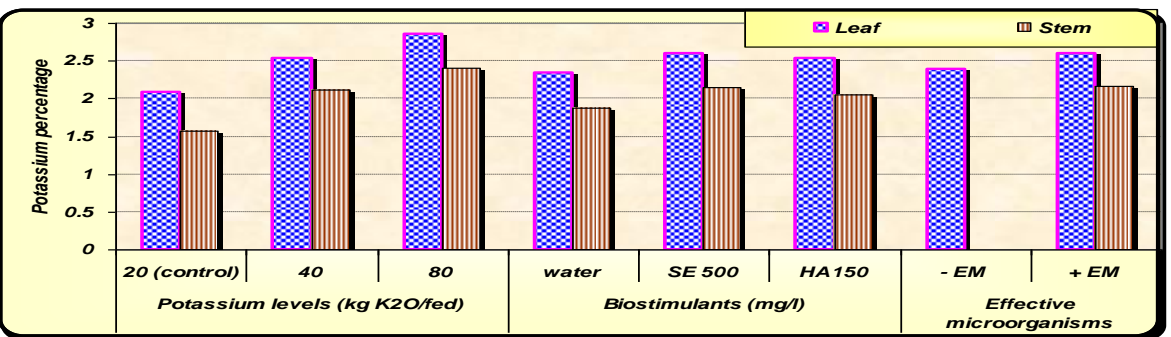

Figure (8):Potassium percentage in both leaves and stem of potato plant as affected by potassium fertilizer, biostimulants or effective microorganisms at 90 days from planting in the second growing season (SE, Seaweed extract; HA, Humic acid)

Table (10): Potassium percentage in both leaves and stem of potato plant as affected by the interactions between potassium fertilizer (A), effective microorganisms (B) and biostimulants (C) at 90 days from planting during the second growing season

\begin{tabular}{|l|c|c|c|c|c|c|}
\hline \multirow{3}{*}{ Treatment } & \multicolumn{7}{|c|}{ Leaves } \\
\cline { 2 - 7 } & \multicolumn{7}{|c|}{ EM } & \multicolumn{3}{c|}{ + EM } \\
\cline { 2 - 7 } & K20 & K40 & K80 & K20 & K40 & K80 \\
\hline Water & 1.893 & 2.307 & 2.492 & 2.124 & 2.576 & 2.639 \\
\hline SE & 2.061 & 2.439 & 2.964 & 2.250 & 2.786 & 3.069 \\
\hline HA & 1.987 & 2.376 & 2.933 & 2.208 & 2.691 & 3.006 \\
\hline LSD 5\% & A 0.1224 & B 0.0820 & C 0.0855 & \multicolumn{2}{|c|}{ ABC NS } \\
\hline Stem & 1.252 & 1.903 & 2.092 & 1.651 & 2.145 & 2.208 \\
\hline Water & 1.557 & 2.040 & 2.450 & 1.809 & 2.345 & 2.733 \\
\hline SE & 1.452 & 1.945 & 2.397 & 1.725 & 2.282 & 2.544 \\
\hline HA & A 0.8715 & B 0.0692 & C 0.0639 & ABC NS \\
\hline LSD 5\%
\end{tabular}

$\left(\mathrm{K}_{20}, 20 \mathrm{~kg} \mathrm{~K} \mathrm{~K}_{2} \mathrm{O}\right.$ fed; $\mathrm{K}_{40}, 40 \mathrm{~kg} \mathrm{~K} \mathrm{~K}_{2} \mathrm{O}$ fed; $\mathrm{K}_{80}, 80 \mathrm{~kg} \mathrm{~K} \mathrm{~K}_{2} \mathrm{O}$ / fed; SE, seaweed extract; $\mathrm{HA}$ humic acid)

\section{DISCUSSION}

Potassium has a crucial role in the energy status of the plant, translocation and storage of assimilates and maintenance of tissue water relations (Marschner, 1995). Potassium application, in particular, $40 \mathrm{~kg}$ $\mathrm{K}_{2} \mathrm{O} / \mathrm{fed}$ improved all vegetative plant growth parameters under the condition of the present investigation. These results are confirmed with the result of Ahmed et al. (2009), and recently by Bhattacharyya et al. (2009) who indicated that application of $180 \mathrm{~kg} \mathrm{~K}$ O/ha recorded higher values of growth attributes like number of leaves per plant, number of stems per plant, ground coverage (\%), number of stolons per plant and total tuber yield. In an earlier study, Huber (1985) reported that $\mathrm{K}^{+}$affects photosynthetic capacity positively because of the dependence of protein synthesis and developmental processes on $\mathrm{K}^{+}$. The obtained results of this study are in agreed with results 
of Ashraf et al. (2002), who found an increase in leaf area approximately of 20 percent with the application of potassium. Moreover, application of $\mathrm{K}$ increased the availability of nitrogen and phosphorus (Sahai, 2004) which resulted in better plant growth and more number of branches per plant. Hanolo and Pulung (1994) have also reported that number of branches per plant in pea increased with increasing $\mathrm{K}$ rate. The present investigation indicated that addition of EM increased, in most cases, growth parameters of potato plants. The presented results are in agreement with those found by many authors, i.e. Muthaura et al. (2010) on pigweed indicated that application of EM increased shoot height $(\mathrm{cm})$, leaf number per plant, stem diameter, leaf area $\left(\mathrm{cm}^{2}\right)$, root dry weight $(\mathrm{g})$, meanwhile decreased leaf fresh weight $(\mathrm{g})$, root fresh weight $(\mathrm{g})$, leaf dry weight $(\mathrm{g})$. The improvement in growth characters may be attributed to the fact that the use of EM enhances the beneficial microbes in the environment (Higa, 2000), which attributed to the profound effect of a) its ability to release plant growth promoting substances which might be stimulated plant growth, b) synthesis of some beneficial organic acids, bioactive substances and vitamins, c) increasing amino acids content (Schank et al., 1981), d) increasing in the water and mineral uptake from the soil leading to improving the availability and acquisition of nutrients from the soil due to increases in root surface area, root hairs and root elongation (Sundaravelu and Muthukrishinan, 1993), e) increasing the ability to convert nitrogen to ammonium and thus make it available to plant, f) enhancing the production of biologically active fungistatical substances which may change the microflora in the rhizosphere and affect the balance between harmful and beneficial organisms (Apte and Shende, 1981), and g) improve the photosynthetic efficiency due to an increase in nutrient availability. It is well known that from the present investigation application of humic acid significantly increased plant growth characteristics. Our results were confirmed with Saif El-Deen et al. (2011) on sweet potato and Farouk et al. (2012) on tomato plants. The mechanism by which humic acid stimulate plant growth are not fully clear, although there are some theories which probably work together. In general, humic acid have two important roles for the development of plants, either directly or indirectly (Nardi et al., 1996) but the mechanism still remain unclear. So far hormonelike substances have been elucidated to understand the mechanism of humic substances in plant metabolism (Muscolo et al., 1999) through their involvement in cell respiration, photosynthesis, oxidative phosphorylation, protein synthesis, and various enzymatic reactions (Zhang et al., 2003). The obtained results in the present investigation showed an increase in potato plant growth due to seaweed extract. Similar results have been reported on okra (Zodape et al., 2008). Recently, Zodape et al., (2011) found that foliar application of seaweed extract on tomato shoot increased plant growth represented as plant height, root length over control plant. The additive effects of enhanced nutrient uptake and regulatory action of plant growth substances contained in the seaweed extract are possible factors in the obtained responses (Crouch and Van Staden 1993). As well as due to the presence of Phenyl Acetic Acid (PAA) and other closely related compounds (P-CH-PAA) in the SE (Taylor and Wilkinson, 1977). The positive effect of SE 
Arafa, A. A. et al.

on plant growth may be due to its effect on increasing phosphorous uptake and content as recorded in the present investigation. Phosphorous is an essential nutrient and it plays an important role in the biosynthesis and translocation of carbohydrates and is necessary in stimulating cell division and the formation of DNA and RNA (Nijjar, 1985).

An addition of potassium fertilizers increased total carbohydrates concentration in both leaves and stems. This observation was confirmed with some investigation reported by Westermann et al. (1994a,b) who indicated that application of potassium fertilizers increased significantly all carbohydrates fractions especially total carbohydrates in plant shoots and leaves. Moreover, foliar application of seaweed extract on potato shoot significantly increased total carbohydrates concentration.

Application of potassium fertilizer under the present investigation resulted in better ion percentage in either leaf or stem. This observation was confirmed with El-Sirafy et al. (2008) who indicated that addition of potassium fertilizer significantly increased $\mathrm{N}, \mathrm{P}$ and $\mathrm{K} \%$ in potato shoots. The positive effect of EM on the nutritional status of potato leaves may be due to that EM contains primarily photosynthetic and lactic acid bacteria, yeast, actinomycetes that can be applied through the inoculation to increase the microbial diversity of the soil, this in turn can improve soil quality and increased significantly the efficacy of the uptake of elements. There is ample evidence that the mode of action of many EM is by increasing the availability of nutrients for the plant in the rhizosphere (Rodriguez and Fraga, 1999). The method by which these increases take place involves solubilization of unavailable forms of nutrients and/or siderophore production which helps facilitate the transport of certain nutrients (notably ferric iron). The favorable effect of EM on $\mathrm{P}$ content may be due to its fundamental role in converting fixed $P$ form to be available for plant nutrition making the uptake of nutrients by plants more easy (Abou-Hussein et al., 2002). The increase in potassium content in the shoot system under EM reflects an enhanced growth which might be possibly due to the role of microorganisms in increasing K-uptake (El-Shahawy, 2003).The effects of humic substances on ion absorption by plant roots are not easily explainable, owing to the complex and still unknown nature of these substances. It has been shown that HA stimulated carrierprotein synthesis in barley roots at a post-transcriptional level (Dell'Agnola et al., 1981). It is well known from some reports presented previously that application of HA increased the water consumption by plants accompanied with the increase of the nutrient uptake which is known to be involved in plant growth by increasing the permeability of membrane of the root cells (Valdrighi et al., 1996) due to improving root growth and development where application of HA stimulate root growth, increased proliferation of root hairs, production of smaller but more ramified secondary roots and enhancement of root initiation (Canellas et al., 2002). This hypothesis was confirmed by significant increase in nitrogen, phosphorous and potassium in treated plant. HA have been reported to stimulate root growth and enable better uptake of nutrients by increasing the permeability of membranes of the root cells (Valdrighi et al., 1996). The present investigation showed that seaweed extracts increased ion content in potato shoot. The obtained results are in conformity with those 
reported by (Zodape et al., 2011) on nutrient uptake with application of seaweed extract. Verkleij (1992) reported an increase in ion uptake with application of SE due to increasing membrane permeability of roots, leaves and stoma cells, and hormone-like activities of SE through their involvement in cell respiration, photosynthesis, and enzymatic reactions.

\section{REFRENCES}

Abou-Hussein S.D., I. El-Oksh, T. El-Shorbagy and A.M.Gomaa (2002a). Effect of cattle manure, bio-fertilizers and reducing mineral fertilizer on nutrient content and yield of potato plant. Egypt J. Hort. 29 (1):99-115.

Ahmed A. A., M.M.H.A. El-Baky, F.S.A. El-Aal and M.F. Zaki (2009). Comparative studies of application both mineral and bio-potassium fertilizers on the growth, yield and quality of potato plant. Research Journal of Agriculture and Biological Sciences. 5 (6):1061-1069.

Apte R. and S.T. Shende (1981). Studies on Azotobacter chroococum and their effect on crop yield. Zbl. Bakt. 136:637-640.

Ashraf M., M. Yousaf, Z.I. Ahmad and A. Amanullah (2002). Effect of K supply on growth and development of maize (Zea mays L.). Pak. J. Soil Sci. 21: 43-48.

Bhattacharyya A., D. Borah and M. Saikia (2009). Effect of potassium on growth, total tuber yield and residual status of nutrients on true potato seed transplants. Crop Research (Hisar) 38(1/3): 88-91.

Cakmak I. (2005). The role of potassium in alleviating detrimental effects of abiotic stresses in plants. J Plant Nutr. Soil Sci. 168:521-530.

Canellas L.P., F.L. Olivares, A.I. Okorokovha and A.R. Facanha (2002). Humic acids isolated from earthworm compost enhance root elongation, lateral root emergence and plasma membrane $\mathrm{H}^{+}$- ATPase activity in maize root. Plant Physiol. 130:1951-1957.

Cooper T.G. (1977). The tools of biochemistry.A Wiley-Interscience Pub. John Wiley and Sons, New York.

Crouch I.J. and J. Van Staden (1993). Evidence for the presence of plant growth regulators in commercial seaweed products. Plant Growth Regulation. 13(1):21-29.

Dell'Agnola G., G. Ferrari and S. Nardi (1981). Antidote action of humic substances on atrazine inhibition of sulphate uptake in barley roots. Pesticide Biochemistry and Physiology 15:101-104.

El-Shahawy A.M.B. (2003.) Effect of phosphate dissolving bacteria on yield and nutrient uptake of faba bean and wheat plants. Ph. D. Thesis, Fac. of Agric., Mansoura Univ., Egypt.

El-Sirafy Z.M., K.A. Abbady, A.M. El-Ghamry and R.A. El-Dissoky (2008). Agroeconomic evaluation of conventional and controlled release potassium fertilizers for potato crop. Australian Journal of Basic and Applied Sciences. 2 (4):1092-1103.

Ezzat A.S., H. EL-S Asfour and M.H. Tolba (2011). Improving yield and quality of some new potato varities in winter plantation using organic stimulators. J. Plant Production, Mansoura Univ., 2(5):653-671. 
Arafa, A. A. et al.

Farouk S., Safaa A. Youssef and Abeer A. Ali (2012). Exploitation of biostimulatants and vitamins as an alternative strategy to control early blight of tomato plants. Asian Journal of Plant sciences, 11(1): 36-43.

Featonby-Smith B.C. and J. van Staden (1987): Effects of seaweed concentrate on grain yield in barely. S Afr J Bot 53:125-128.

Fike J.H.,V.G. Allen, R.E. Schmidt, X. Zhang, J.P. Fontenot, C.P. Bagley, R.L. Ivy, R.R. Evans, R.W. Coelho and D.B. Wester (2001). TascoForage: I. Influence of a seaweed extract on antioxidant activity in tall fescue and in ruminants. J Anim Sci 2001. 79:1011-1021.

Gedroits K.K. (1963). Chemical analysis of soils. Ed. National Sci Foundation, Washington Dc. By The Isreal program for scientific translation, Jerusalem.

Hanolo W. and M.A. Pulung (1994). Effect of $P$ and $K$ fertilizers on growth and yield of pea. Acta Hort. Bogor Indonesia, 369:335-339.

Higa T. (1995). Effective microorganisms: Their role in Kyusei Nature Farming and sustainable agriculture. In J.F. Parr, S.B. Hornick, and M.E. Simpson (ed.) Proceedings of the Third International Conference on Kyusei Nature Farming. U.S. Department of Agriculture, Washington, D.C., USA.

Higa T. (2000). What is EM technology? EM World J. 1:1-6

Huber S.C. (1985). Role of potassium in photosynthesis and respiration. In Potassium in Agriculture, 369-395. (Ed.): R.D. Muson. ASA-CSSASSSA, Madison, WI, USA.

Kanai S, K. Ohkura, J.J. Adu-Gyamfi, P.K. Mohapatra, N.T. Nguyen, H. Saneoka and K. Fujita (2007). Depression of sink activity precedes the inhibition of biomass production in tomato plants subjected to p[potassium deficiency stress. J Experimental Bot 58:2917-2928

Koller H.R. (1972). Leaf area-leaf weight relationships in the Soybean canopy. Crop Sci., 12(3/4):180-183.

Marschner H. (1995). Functions of mineral nutrients: macronutirents. In: Marschner $\mathrm{H}$ (ed) Mineral nutrition of higher plants, 2nd edn. Academic, N.Y, pp 299-312.

Muscolo A., F. Bavolo, F. Gionfriddo and S. Nardi (1999). Earthworm humic matter produced auxin-like effects on Daucus carota cell growth and nitrate metabolism. Soil Biol. Biochem. 31:1303-1311.

Muthaura C., D.M. Musyimi, J.A. Ogur and S.V. Okello (2010). Effective microorganisms and their influence on growth and yield of pigweed (Amaranthus dubians). ARPN J. of Agric. Biol. Sci. 5(1):167-22.

Nardi S., G. Concheri and Dell Angola (1996). Biotical activity of hamic substances. In: piccolo A., (Ed.) Hamic substances in Terrestrial Ecosystems, Elsevier. Amsterdam, PP.361-406.

Nijjar G.S. (1985). Nutrition of fruit trees. Usha Raji Kumar, Kalyani, New Delhi, India, pp 10-20

Norman G.R. and D.L. Streiner (2003). PDQ Statistics, 3rd Ed. BC Deckker Inc, London.

Perrenoud S. (1993). Fertilizing for high yield potato. IPI Bulletin 8. $2^{\text {nd }}$ Edition, International Potash Institute, Basel, Switzerland. 
Pettigrew W.T. (1999). Potassium deficiency increases specific leaf weights and leaf glucose levels in field-grown cotton. Agron J. 91:962-968

Pettigrew W.T. (2008). Potassium influences on yield and quality production for maize, wheat, soybean and cotton. Physiol. Plant. 133:670-681

Piccolo A., S. Nardi and G. Concheri (1992). Structural characteristics of humic substances as regulated to nitrate uptake and growth regulation in plant systems. Soil Biochem., 24:373-380.

Rodriguez H. and R. Fraga (1999). Phosphate solubilizing bacteria and their role in plant growth promotion. Biotechnol. Adv. 17:319-339.

Sadasivam S. and A. Manickam (1996). Biochemical methods, Second eddition, New age international. India.

Sahai V.N. (2004). Mineral Nutrients. In Fundamentals of Soil. $3^{\text {rd }}$ Edition. Kalyani Publishers, New Dehli, India. pp:151-155.

Saif El-Deen U.M., A.S. Ezzat and A.H.A. EL-Morsy (2011). Effect of phosphorous fertilizer rates and application methods of humic acid on productivity and quality of sweet potato. J. Plant Production, Mansoura Univ., 2(1):53-66.

Sangakkara U.R., M. Frehner and J. Nosberger (2000). Effect of soil moisture and potassium fertilizer on shoot water potential, photosynthesis and partitioning of carbon in mungbean and cowpea. J. Agron. Crop Sci. 185: 201-207.

Schank S.C., K.L. Weier and I.C. Macrae (1981). Plant yield and nitrogen content of a digitgrass in response to Azospirillum inoculation. Appl. Environ. Microbiol. 41:342-345.

Sundaravelu S. and T. Muthukrishinan (1993). Effect of seed treatment with Azospirillium and gibberellic acid on the growth and yield of radish. South India Hort. 41(4):212-213.

Taylor I.E.P. and A.J. Wilkinson (1977). The occurrence of gibberellins and gibberellins-like substances in algae, J. Phycologia. 16:37-42.

Valdrighi M.M., A. Pear, M. Agnolucci, S. Frassinetti, D. Lunardi and G. Vallini (1996). Effects of compost-derived humic acids on vegetable biomass production and microbial growth within a plant (Cichorium intybus) soil system: a comparative study. Agric. Ecosyst. Environ. 58:133-144.

Verkleij F.N. (1992). Seaweed extracts in agriculture and horticulture: a review. Biol Agric Hort 8:309-324

Westermann D.T., D.W. James, T.A. Tindall and R.L. Hurst (1994a) Nitrogen and potassium fertilization of potatoes: Sugars and starch. Amer Potato J 71:433-453

Westermann D.T., T.A. Tindall, D.W. James and R.L. Hurst (1994b) Nitrogen and potassium fertilization of potatoes: Yield and specific gravity. Amer Potato J 71:417-431

Zhang X., E.H. Ervin and R.E. Schmidt (2003). Plant growth regulators can enhance the recovery of Kentucky bluegrass sod from heat injury. Crop Sci. 43:952-956. 
Arafa, A. A. et al.

Zodape S.T., Abha Gupta, S.C. Bhandari, U.S. Rawat, D.R. Chaudhary, K. Eswaran and A. Chikara (2011). Foliar application of seaweed sap as biostimulant for enhancement of yield and quality of tomato (Lycopersicon esculentum Mill.). J. of Scientific and Industrial Research, 70: 215-219.

Zodape S.T., V.J. Kawarkhe, J.S. Patolia and A.D. Warade (2008). Effect of liquid seaweed fertilizer on yield and quality of okra (Abelmoschus esculentus L.). J. of Scientific and Industrial Research, 67:1115-1117

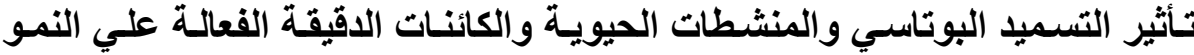

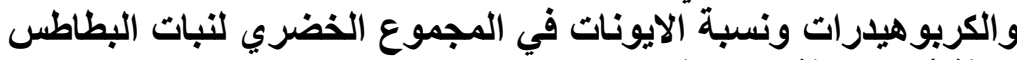

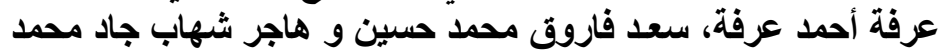

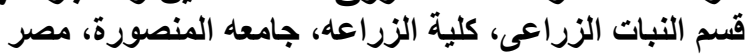

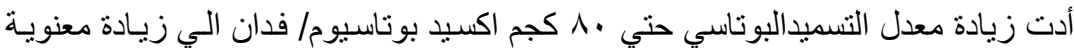

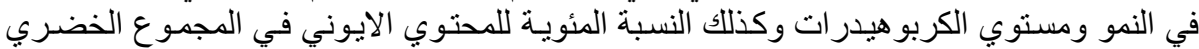

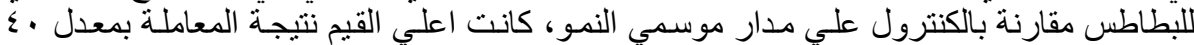

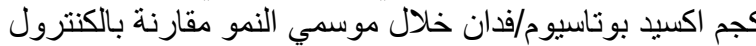

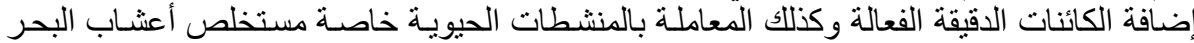

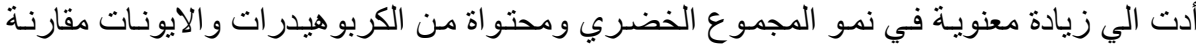

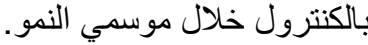

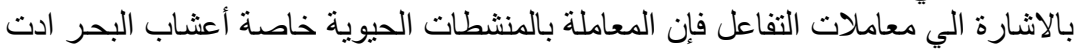

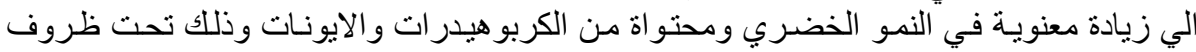

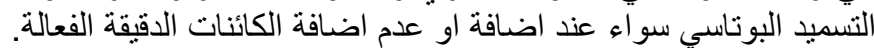

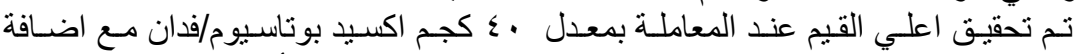

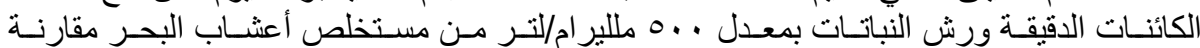

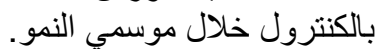

كلية الزراعة - جامعة المنصورة كلية الزراعة - جامعة القاهره

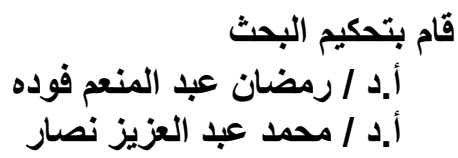

